Nevada

Environmental

Restoration

Project

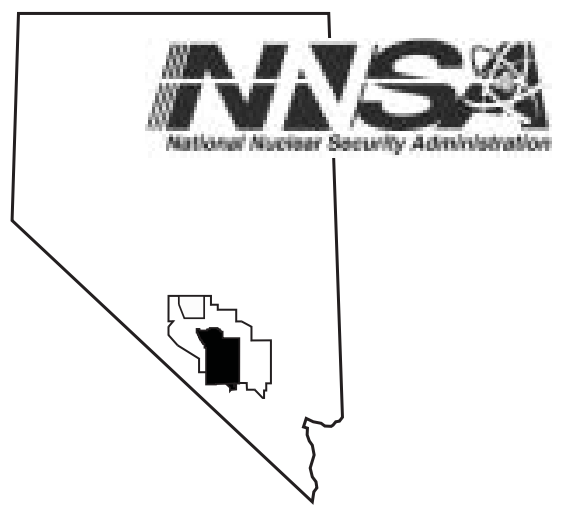

Post-Closure Inspection Report for Corrective Action Unit 90: Area 2 Bitcutter Containment Annual Report, Nevada Test Site, Nevada

Controlled Copy No.:

Revision: 0

September 2003

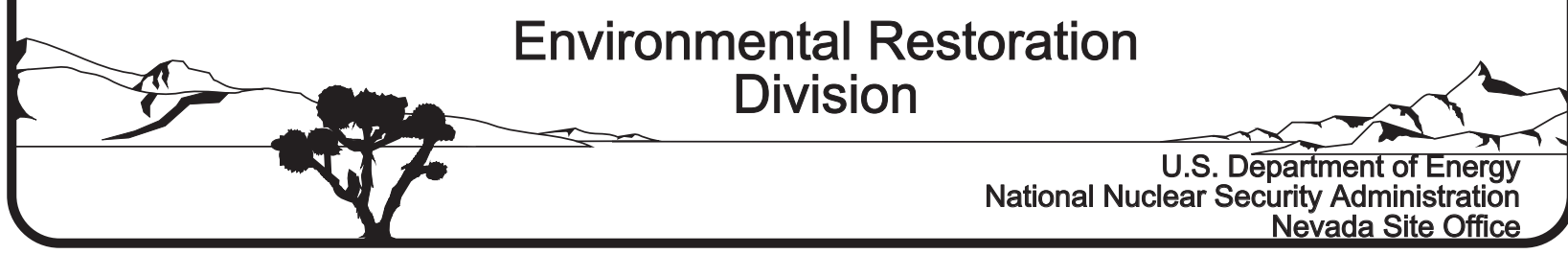




\section{DISCLAIMER STATEMENT}

Reference herein to any specific commercial product, process, or service by trade name, trademark, manufacturer, or otherwise, does not necessarily constitute or imply its endorsement, recommendation, or favoring by the U.S. Government or any agency thereof or its contractors or subcontractors.

\section{AVAILABILITY STATEMENT}

Available for sale to the public from-

U.S. Department of Commerce

National Technical Information Service

5285 Port Royal Road

Springfield, VA 22161-0002

Telephone: 800.553 .6847

Fax: 703.605.6900

E-mail: orders@ntis.gov

Online ordering: http://www.ntis.gov/ordering.htm

Available electronically at http://www.osti.gov/bridge

Available for a processing fee to U.S. Department of Energy and its contractors, in paper, from-

U.S. Department of Energy

Office of Scientific and Technical Information

P.O. Box 62

Oak Ridge, TN 37831-0062

Telephone: 865.576 .8401

Fax: 865.576.5728

E-mail: reports@adonis.osti.gov 


\title{
POST-CLOSURE INSPECTION REPORT FOR CORRECTIVE ACTION UNIT 90: AREA 2 BITCUTTER CONTAINMENT ANNUAL REPORT, NEVADA TEST SITE, NEVADA
}

\author{
Prepared for \\ U.S. Department of Energy \\ National Nuclear Security Administration \\ Nevada Site Office \\ Work Performed Under Contract No. \\ DE-AC08-96NV11718
}

Controlled Copy No.:

Revision: 0

September 2003 
THIS PAGE INTENTIONALLY LEFT BLANK 


\section{POST-CLOSURE INSPECTION REPORT FOR CORRECTIVE ACTION UNIT 90: AREA 2 BITCUTTER CONTAINMENT ANNUAL REPORT, NEVADA TEST SITE, NEVADA}

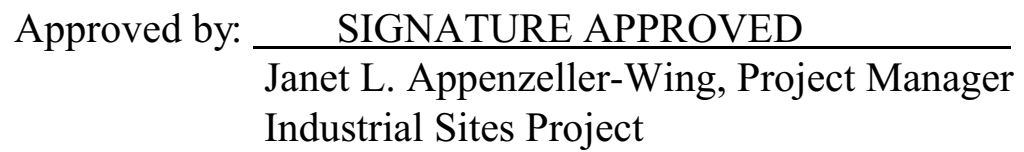

\footnotetext{
Approved by: SIGNATURE APPROVED Runore C. Wycoff, Division Director
} Environmental Restoration Division
Date: $8 / 13 / 03$

Date: $8 / 13 / 03$ 
THIS PAGE INTENTIONALLY LEFT BLANK 


\section{TABLE OF CONTENTS}

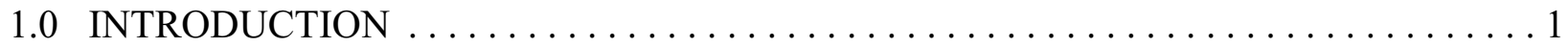

2.0 RESULTS OF THE INSPECTIONS $\ldots \ldots \ldots \ldots \ldots \ldots \ldots \ldots \ldots \ldots \ldots \ldots \ldots$

3.0 CONCLUSIONS AND RECOMMENDATIONS $\ldots \ldots \ldots \ldots \ldots \ldots \ldots \ldots \ldots \ldots \ldots$

\section{ATTACHMENTS}

A. POST-CLOSURE INSPECTION CHECKLISTS

B. FIELD NOTES

C. INSPECTION PHOTOGRAPHS

DISTRIBUTION LIST 
Post Closu re Inspection R eport

CAU 90 - Area 2 Bitcutter

Revis ion: 0

Date: September 2003

THIS PAGE INTENTIONALLY LEFT BLANK 


\subsection{INTRODUCTION}

Area 2 Bitcutter and Post-Shot Containment Wells Corrective Action Unit (CAU) 90 Post-Closure Monitoring requirements are described in Section VII.B.8.b of the Nevada Test Site Resource Conservation and Recovery Act Permit for a Hazardous Waste Management Facility Number NEV HW009, Section VII, Revision 1, March 2003.

Post-closure care consists of the following:

- Semiannual inspections of the unit using an inspection checklist

- Photographic documentation

- $\quad$ Field note documentation

- $\quad$ Preparation and submittal of an annual report

The annual report consists of copies of the inspection checklist, repair records (if any), photographs, and recommendations and conclusions for the period December 2002 to June 2003. The Post-Closure Inspection Checklists are provided in Attachment A, a copy of the field notes is provided in Attachment B, and copies of the inspection photographs are provided in Attachment C.

\subsection{RESULTS OF THE INSPECTIONS}

The first inspection at CAU 90 for the annual post-closure monitoring period was performed on December 19, 2002. Between July and December of 2002, small animal burrows were periodically backfilled. Two animal burrows were backfilled and vegetation was noted growing on the soil covers during the December inspection.

The second inspection at CAU 90 for the annual post-closure monitoring period was performed on June 26, 2003. Between January and June of 2003, several animal burrows were backfilled and vegetation was removed from the covers.

\subsection{CONCLUSIONS AND RECOMMENDATIONS}

The overland runoff is being properly diverted around the site. No evidence of drainage or erosion is apparent through the site. Inspectors should continue to backfill small animal burrows and remove vegetation from the unit. No significant modifications or repairs are foreseeable in the near future. 
Post Closu re Inspection R eport

CAU 90 - Area 2 Bitcutter

Revis ion: 0

Date: September 2003

THIS PAGE INTENTIONALLY LEFT BLANK 
Post Closu re Inspection R eport

CAU 90 - Area 2 Bitcutter Revis ion: 0

Date: September 2003

THIS PAGE INTENTIONALLY LEFT BLANK 
AREA 2, BITCUTTER \& POSTSHOT INJECTION WELLS, POST-

CLOSURE INSPECTION CHECKLIST

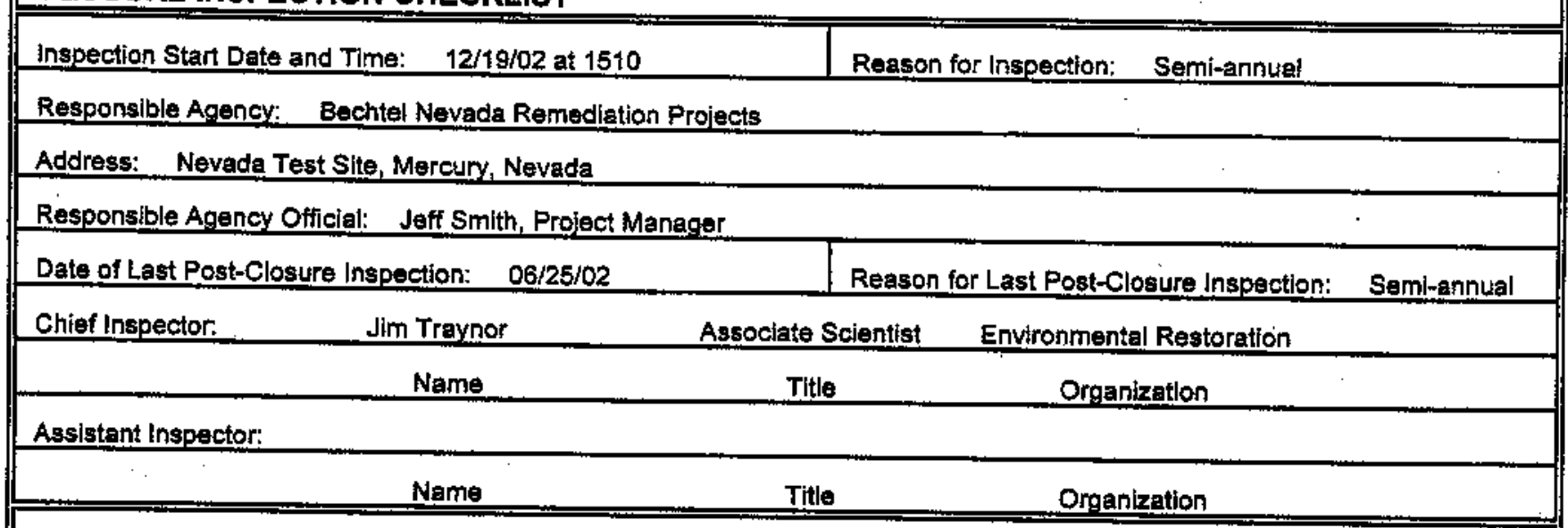

A. GENERAL INSTRUCTIONS

1. All checklist items must be completed and deteiled comments made to document the results of the site Inspection. The completed checklist is part of the field record of the inspectlon. Additional pages should be used as necessary to ensure that a complete record Is made. Attach the additional pages and number all pages upon completion of the inspection.

3. Any checklist line ttem marked by an inspector in a SHADED BOX, must be fully explalned or an appropriate reference to previous reports provided. The purpose of this requirement is to provide a written explanation of inspector observations and the inspector's rationale for conclusions and recommendations. Explanations are to be placed on additional attachments and cross-referenced appropriately. Explenations, in addition to narrative, will take the form of sketches. measurements, annotated site maps.

4. The slte inspection is a walking inspection of the entire site including the perimeter and sufficient transects to be able to inspect the entire surface and all features specifically described in this checklist.

5. A standard set of color $35 \mathrm{~mm}$ photographs is required. In addition, all anomalous features or new features (such as changes in adjacent area land use) are to be photographed. A photo log entry will be made for each photograph taken.

6. This unit will be inspected blannually with formal reporting to the Nevada Division of Environmental Protection to be done annually. The annual report will include an executive summary, this inspection checklist with field notes and photo log attached, and recommendations and conclusjons.

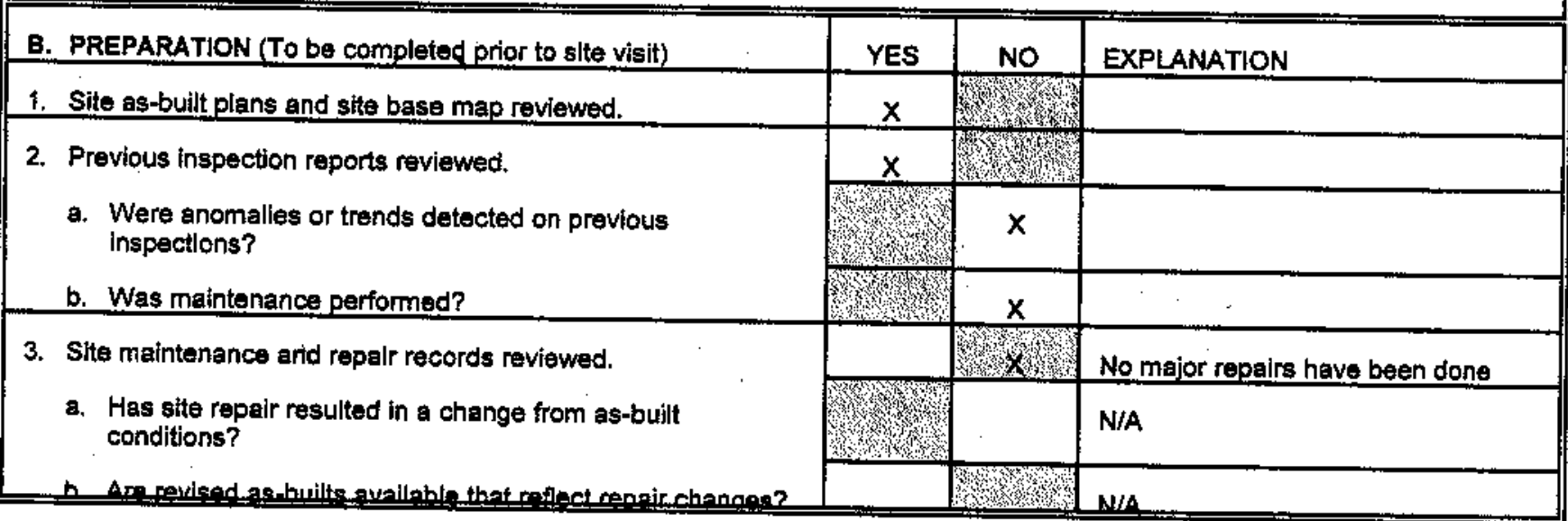




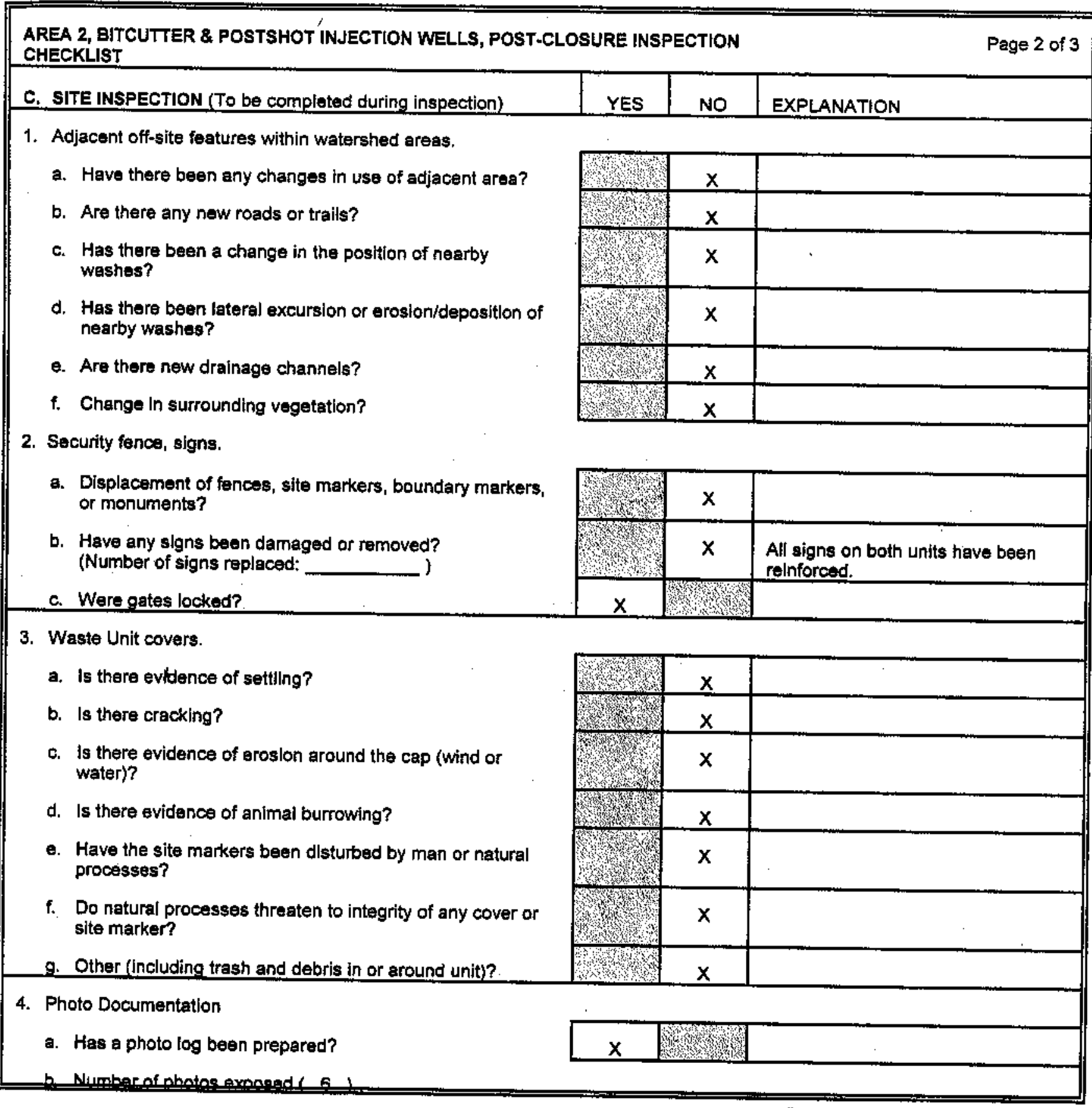


AREA 2, BITCUTTER \& POSTSHOT INJECTION WELLS, POST-CLLOSURE INSPECTION
CHECKLST

\section{FIELD CONCLUSIONS}

1. is there an imminent hazard to the integrity of the unit? (Immediate report required)

\begin{tabular}{|c|c|c|}
\hline YES & No & EXPLANATION \\
\hline & $x$ & \\
\hline
\end{tabular}

Person/Agency to whom report made:

\section{Are more frequent inspections required?}

3. Are existing maintenance/repair actions satisfactory?

4. Is other maintenance/repair necessary?

5. Fieid conclusions/recommendations:

Al! observations indicate continued integrity of the unit. Continue Inspections as scheduled.

\section{E. CERTIFICATION}

1 have conducted an Inspection of the Area 2 Bitcutter \& Postshot Shop Containment Injection Wells, Corrective Action Unit 90, at the NTS in accordance with the procedures of the Post-Closure Permit (including the Post-Closure Plan) as recorded on this checklist, attached sheets, field notes, photo logs, and phetographs.

Chief Inspector's Signature:

Title: Assaciate Scientist Printed Name: Jim Traynor 
Post Closu re Inspection R eport

CAU 90 - Area 2 Bitcutter

Revis ion: 0

Date: September 2003

THIS PAGE INTENTIONALLY LEFT BLANK 


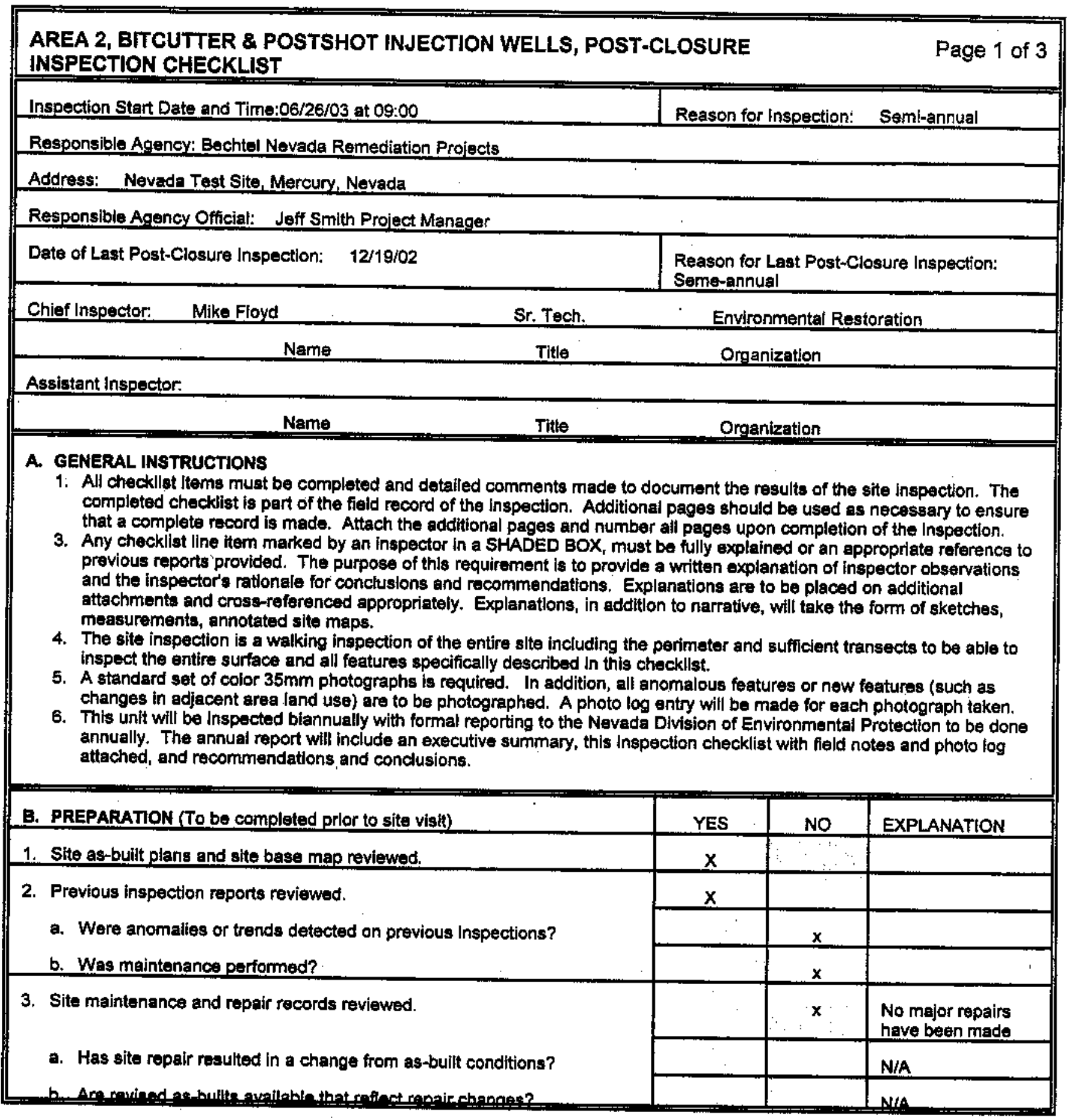




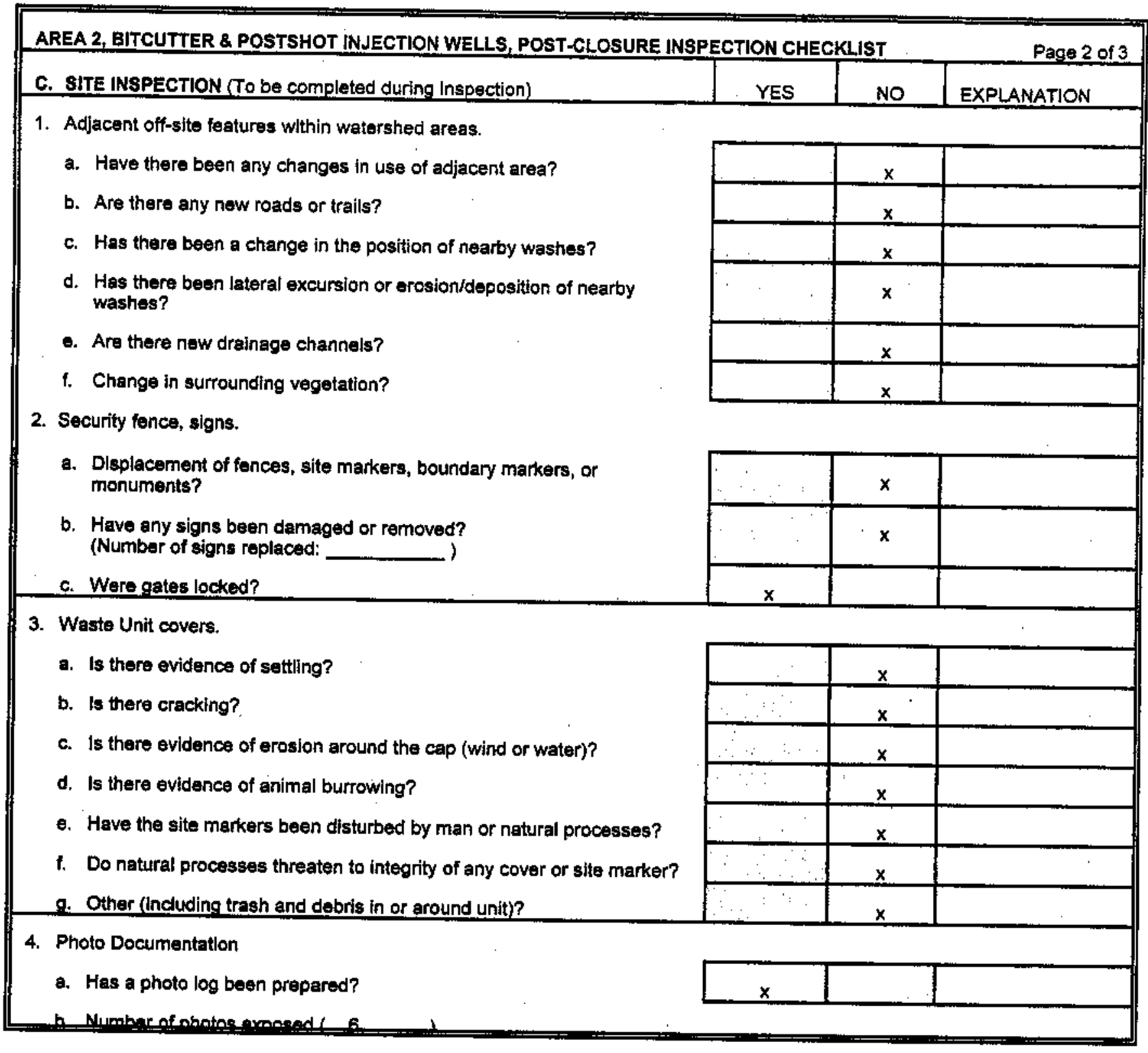




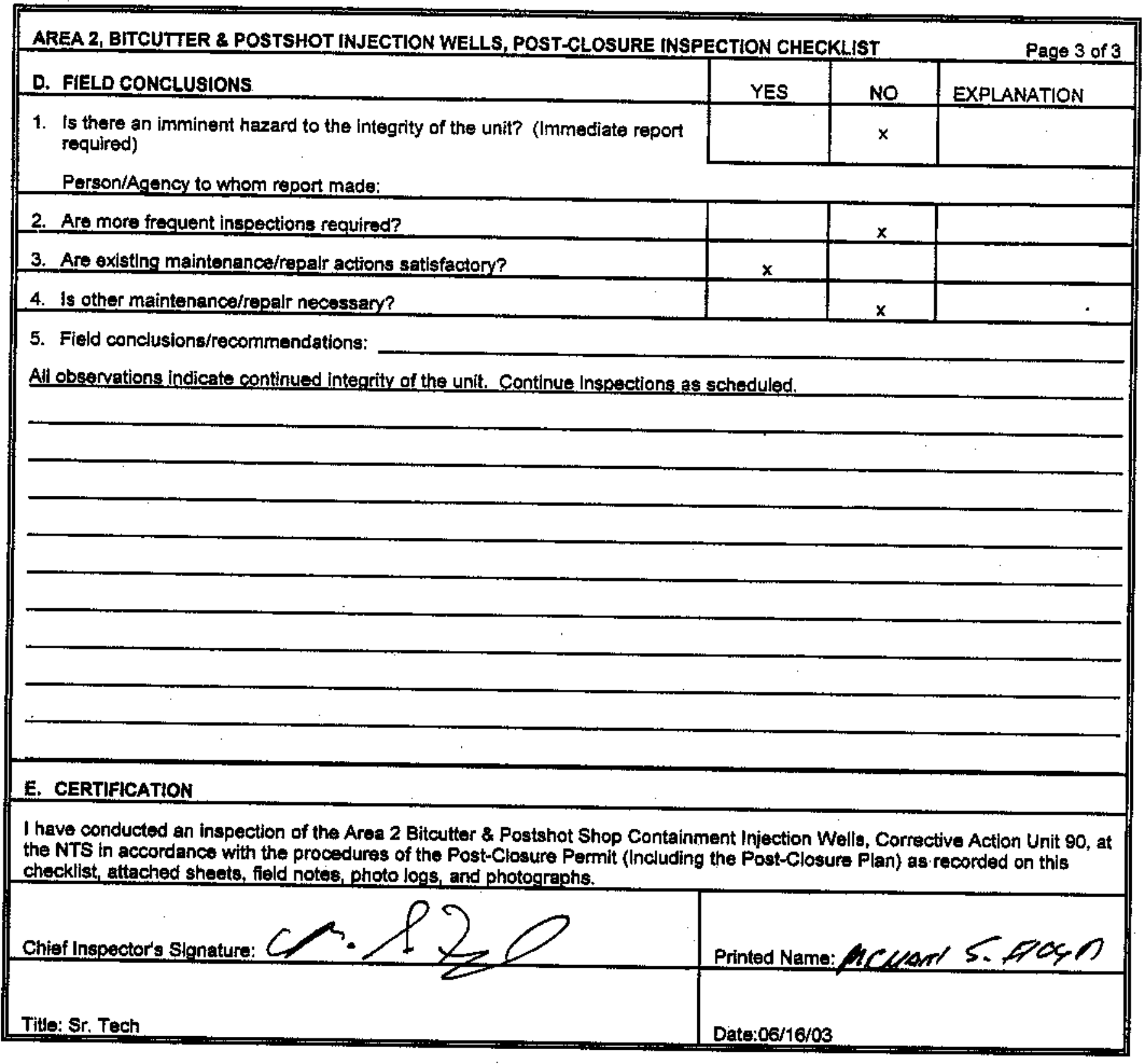


Post Closu re Inspection R eport

CAU 90 - Area 2 Bitcutter

Revis ion: 0

Date: September 2003

THIS PAGE INTENTIONALLY LEFT BLANK 
Post Closu re Inspection R eport

CAU 90 - Area 2 Bitcutter

Revis ion: 0

Date: September 2003

\section{ATTACHMENT B}

\section{FIELD NOTES}


Post Closu re Inspection R eport

CAU 90 - Area 2 Bitcutter Revis ion: 0

Date: September 2003

THIS PAGE INTENTIONALLY LEFT BLANK 
70 III LE

Work continued from Page

rowstal mu.

BOOK NO.

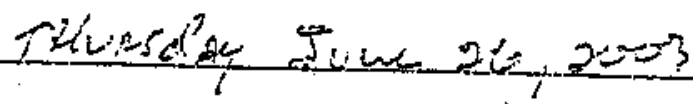

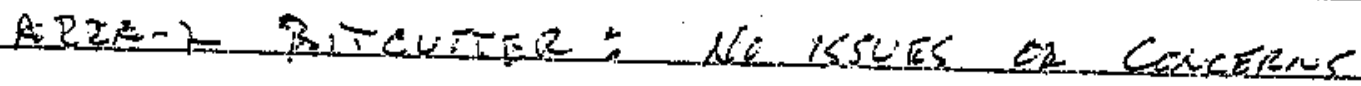

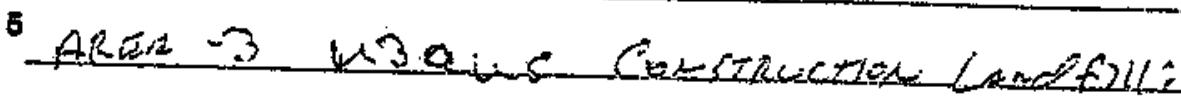

NO ISLES OR CONEETSS

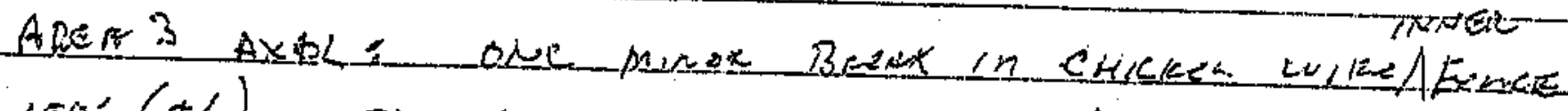

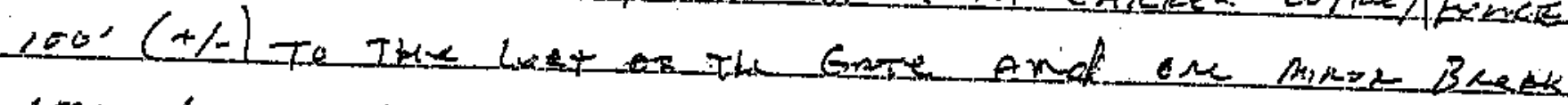

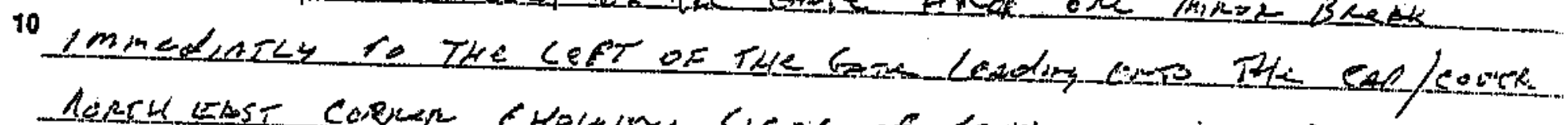

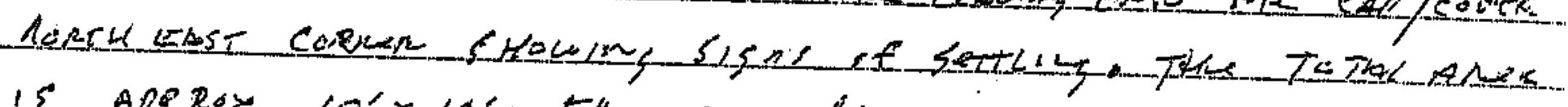

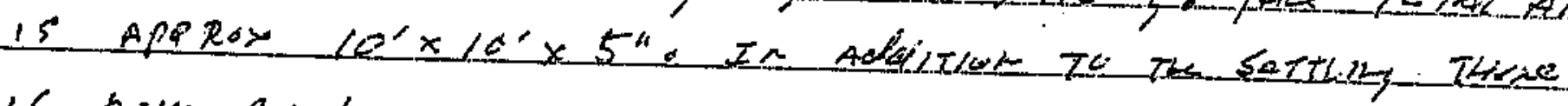

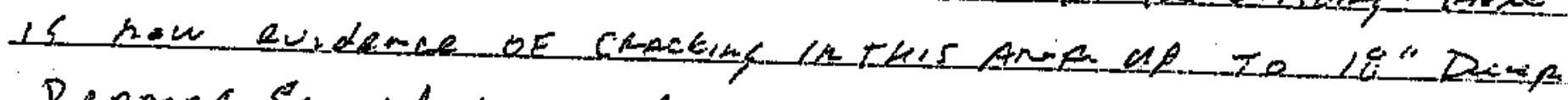

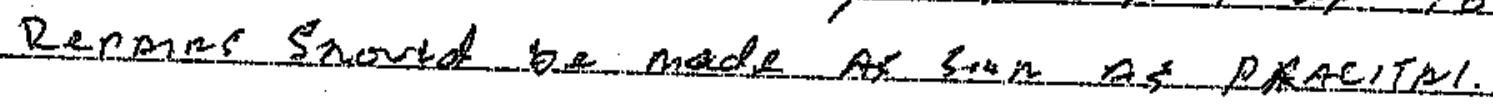

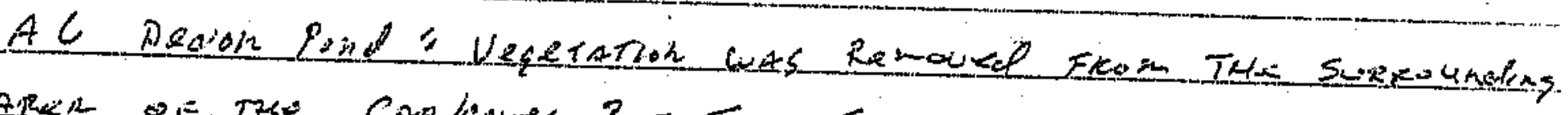

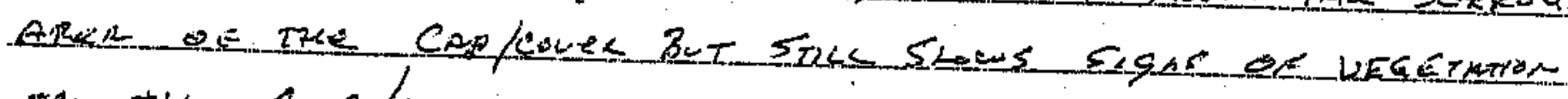

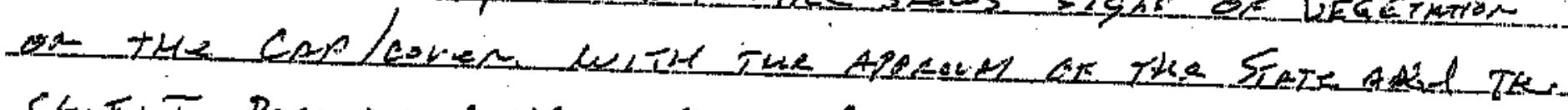

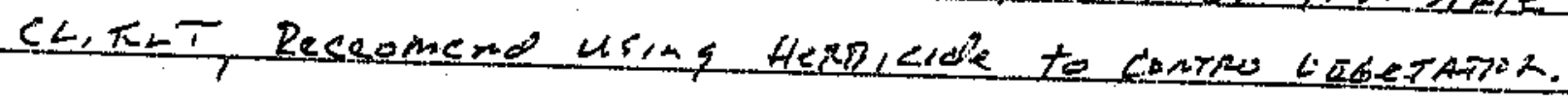

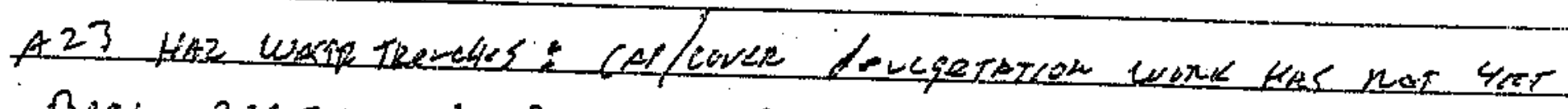

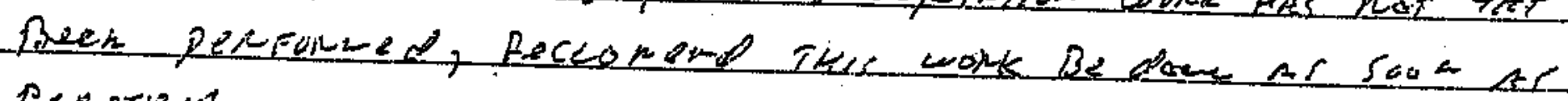
Pensteat,

25

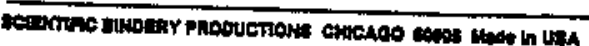

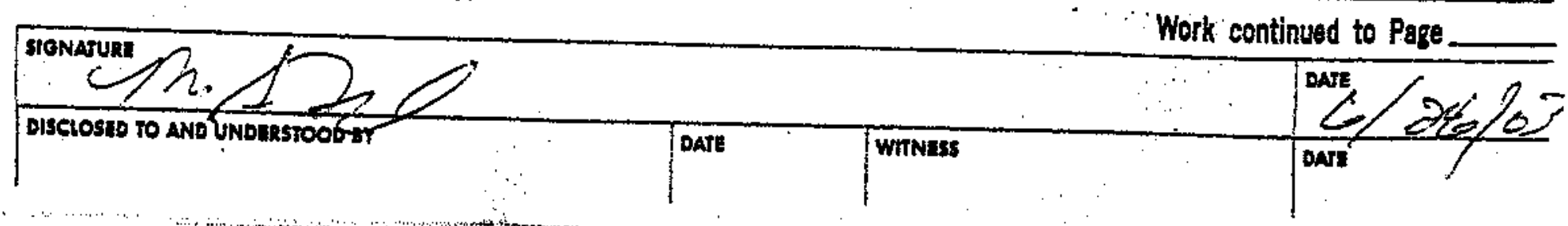




\section{ATTACHMENT C}

\section{INSPECTION PHOTOGRAPHS}


Post Closu re Inspection R eport

CAU 90 - Area 2 Bitcutter Revis ion: 0

Date: September 2003

THIS PAGE INTENTIONALLY LEFT BLANK 


\section{PHOTOGRAPH LOG}

\begin{tabular}{||c|c|l||}
\hline $\begin{array}{c}\text { PHOTO } \\
\text { NUMBER }\end{array}$ & \multicolumn{2}{c||}{ DATE } \\
\hline $1 \mathrm{a}$ & $\begin{array}{c}12 / 19 / 2002 \\
6 / 26 / 2003\end{array}$ & View looking north from east unit. \\
\hline $\mathrm{b}$ & $12 / 19 / 2002$ & View looking north from west unit. \\
\hline $2 \mathrm{a}$ & $6 / 26 / 2003$ & \\
\hline $\mathrm{b}$ & $12 / 19 / 2002$ & View looking south from west unit. \\
\hline $3 \mathrm{a}$ & $6 / 26 / 2003$ & \\
\hline $3 \mathrm{~b}$ & $12 / 19 / 2002$ & View looking west from east unit. \\
\hline $4 \mathrm{a}$ & $6 / 26 / 2003$ & \\
\hline $4 \mathrm{~b}$ & $12 / 19 / 2002$ & View looking east from west unit. \\
\hline $5 \mathrm{a}$ & $6 / 26 / 2003$ & \\
\hline $5 \mathrm{~b}$ & $12 / 19 / 2002$ & \\
\hline $6 \mathrm{a}$ & $6 / 26 / 2003$ & View looking south from east unit. \\
\hline $6 \mathrm{~b}$ & & \\
\hline \hline
\end{tabular}


Post Closu re Inspection R eport

CAU 90 - Area 2 Bitcutter

Revis ion: 0

Date: September 2003

THIS PAGE INTENTIONALLY LEFT BLANK 
Revision: 0

Date: September 2003

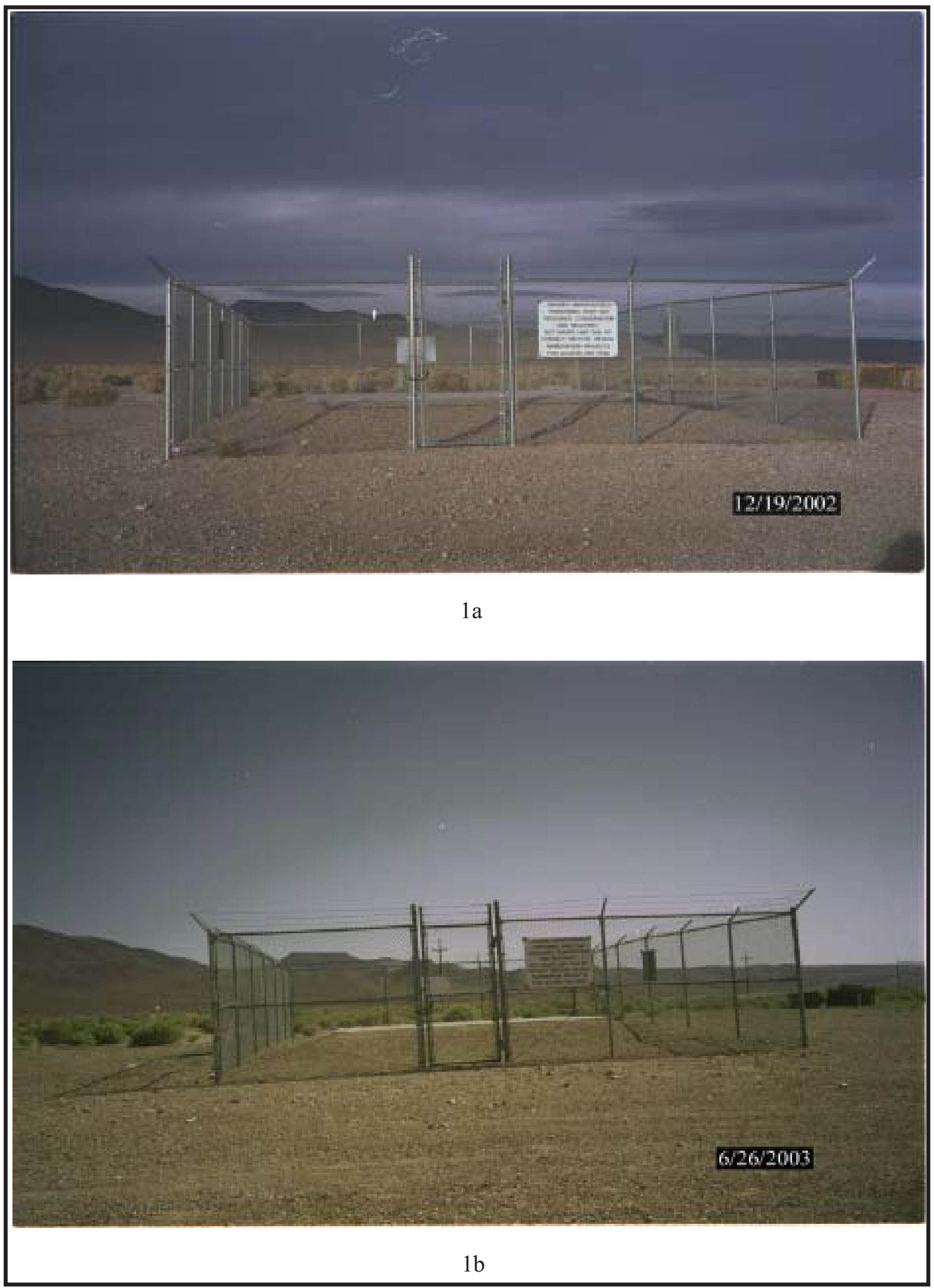

C-3 
CAU 90-Area 2 Bitcutter

Revision: 0

Date: September 2003

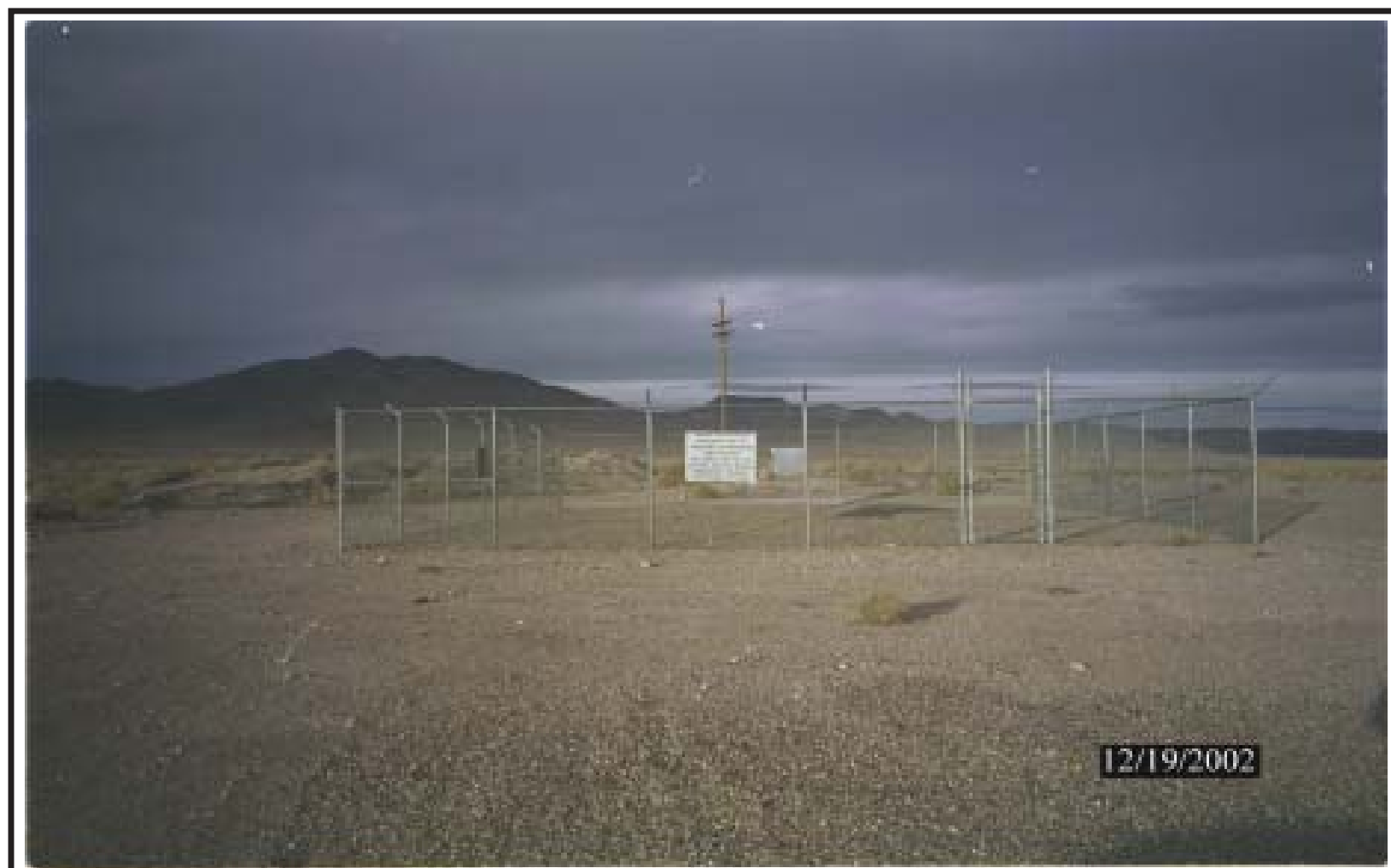

$2 \mathrm{a}$

$6 / 26 / 2003$ 
CAU 90-Area 2 Bitcutter

Revision: 0

Date: September 2003

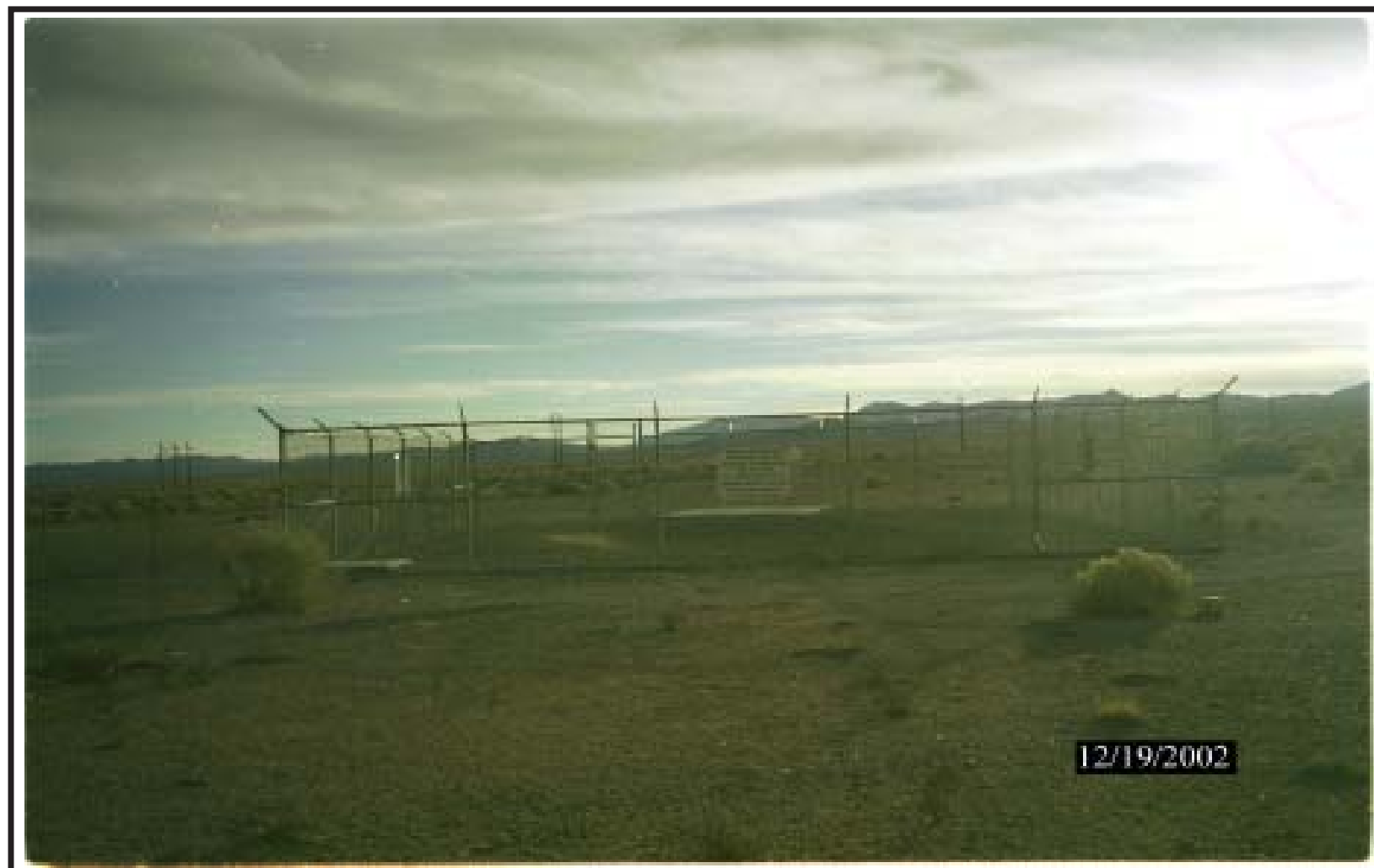

$6 / 26 / 2003$ 
CAU 90-Area 2 Bitcutter

Revision: 0

Date: September 2003

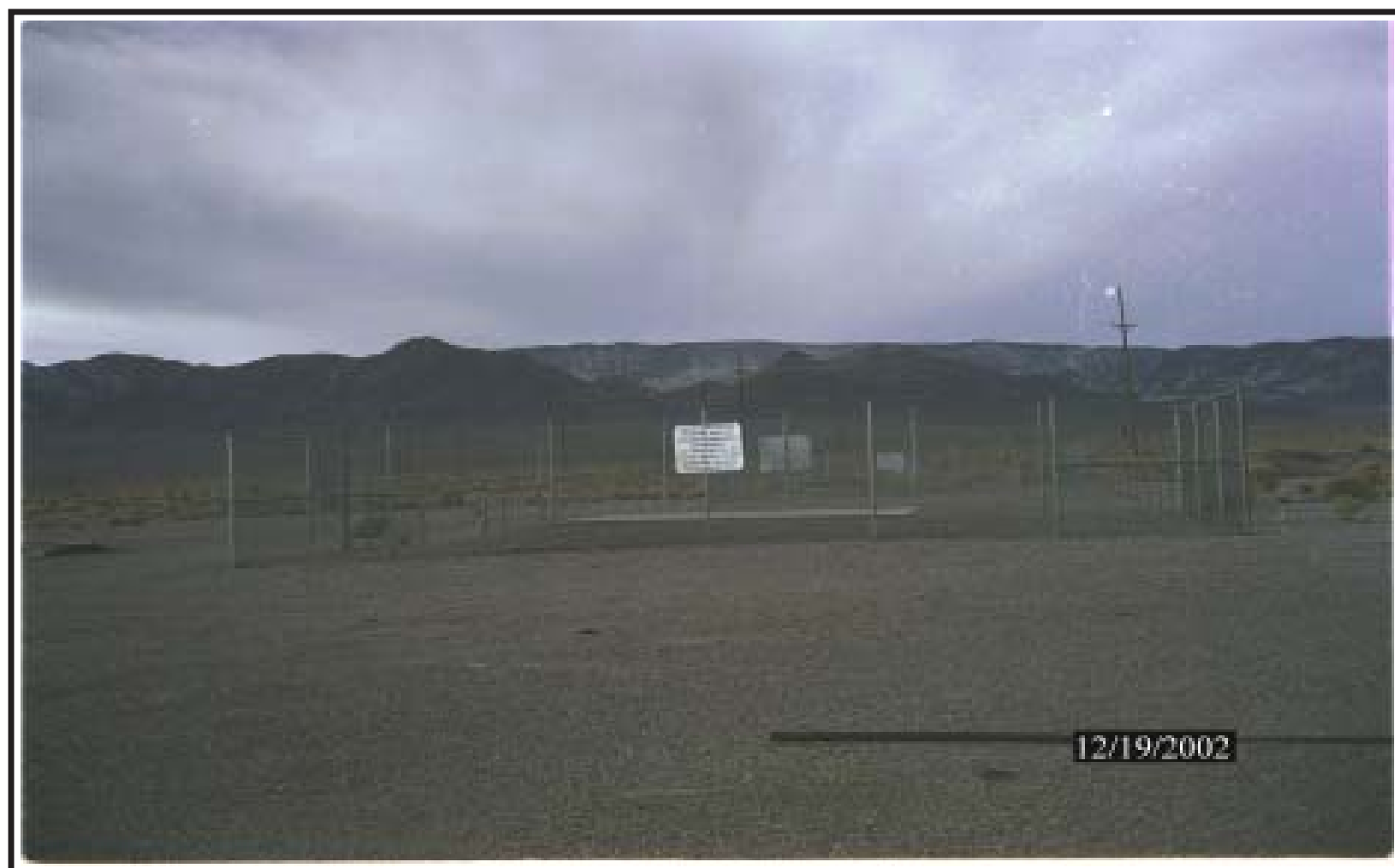

$4 a$

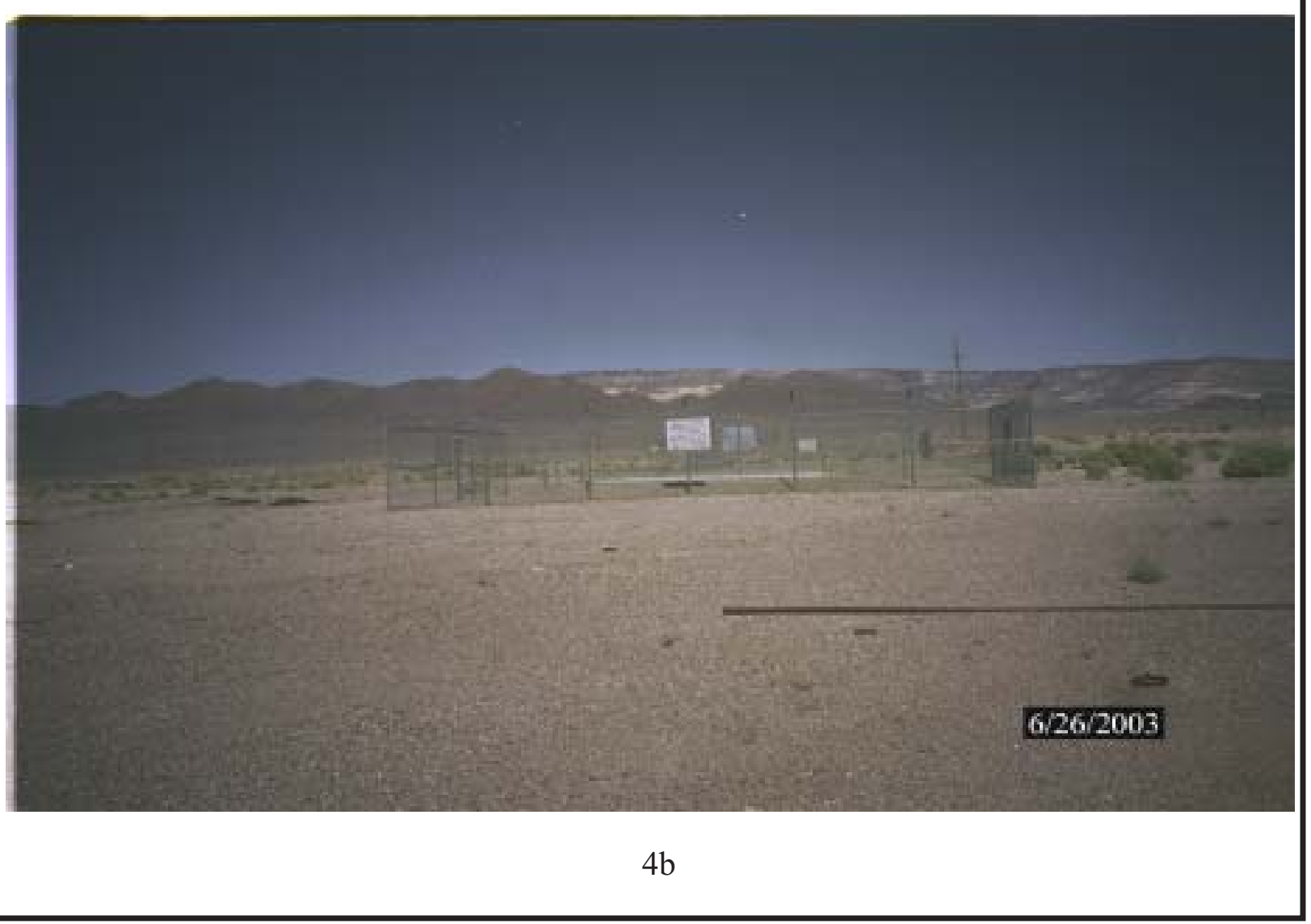

C-6 


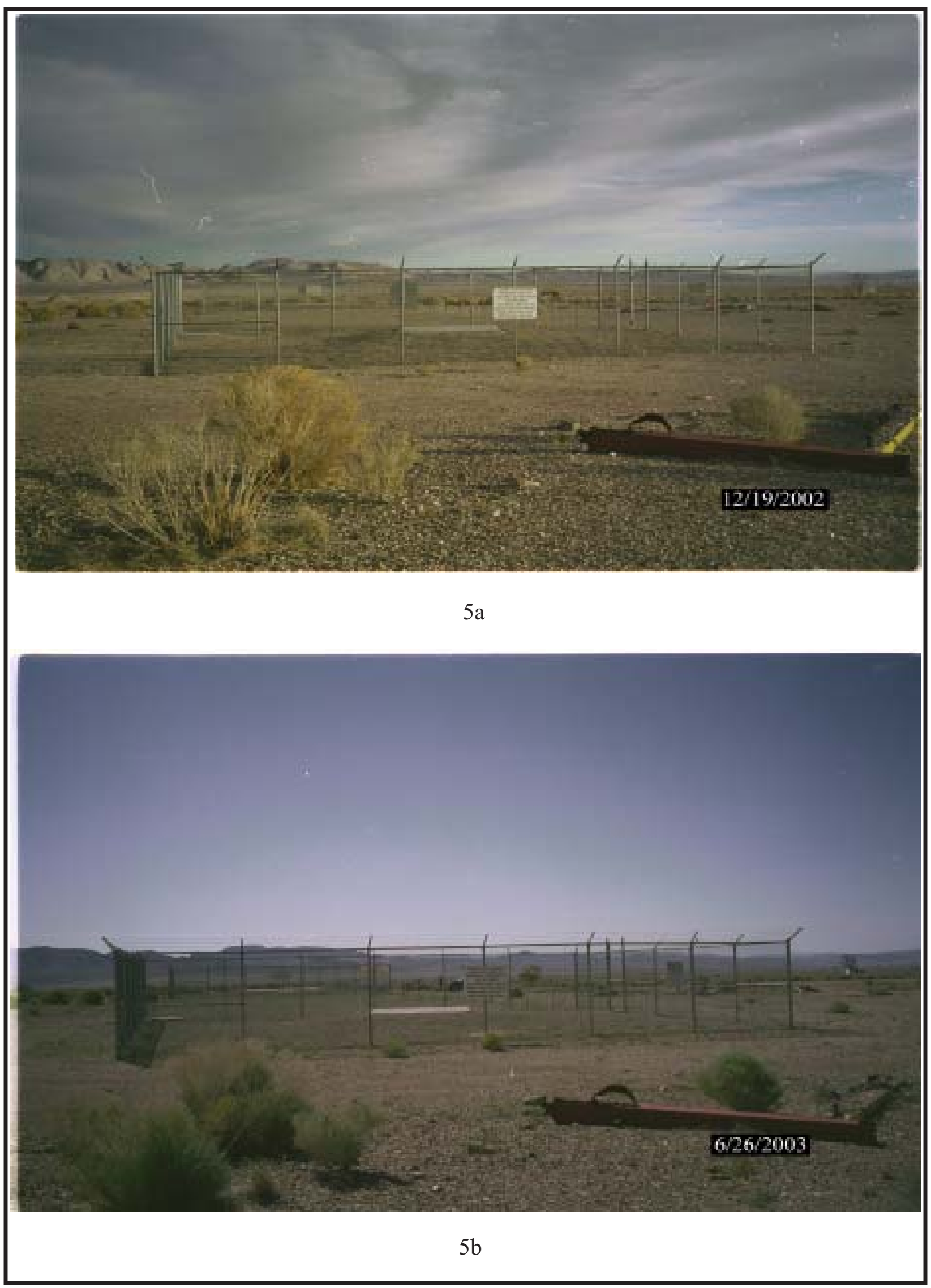




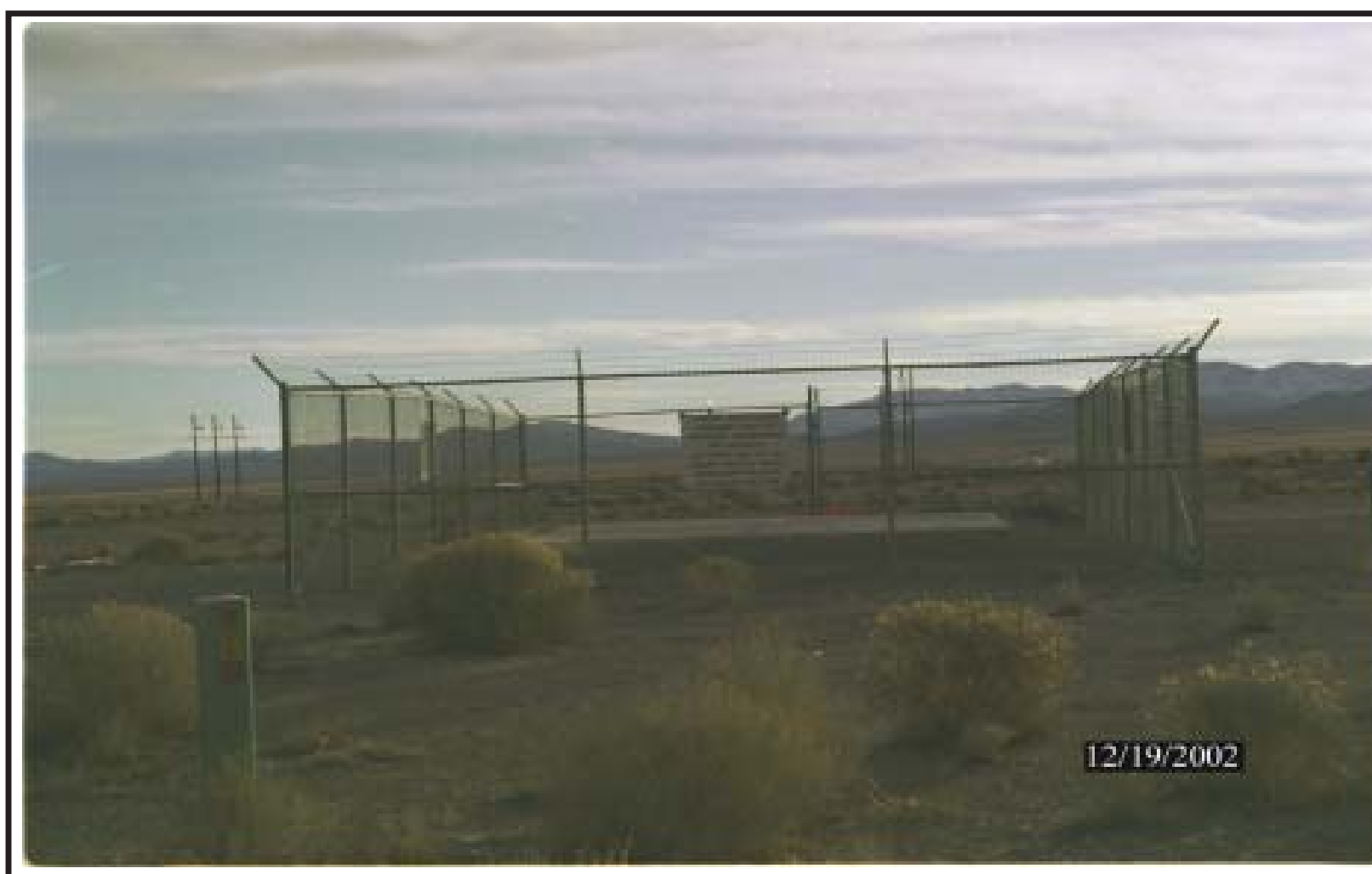

$6 a$ 
Post Closu re Inspection R eport

CAU 90 - Area 2 Bitcutter

Revis ion: 0

Date: September 2003

\section{DISTRIBUTION LIST}


Post Closu re Inspection R eport

CAU 90 - Area 2 Bitcutter Revis ion: 0

Date: September 2003

THIS PAGE INTENTIONALLY LEFT BLANK 


\section{DISTRIBUTION LIST}

*Provide copy of initial distribution of all revisions; others receive NDEP-approved revision only.

\section{$\underline{\text { Nevada Division of Environmental Protection }}$}

Paul Liebendorfer

$1($ Controlled)*

Bureau of Federal Facilities

Division of Environmental Protection

333 W. Nye Lane, Room 138

Carson City, NV 89706-0866

Donald Elle

Bureau of Federal Facilities

$1(\text { Controlled })^{*}$

Division of Environmental Protection

1771 East Flamingo Road, Suite 121-A

Las Vegas, NV 89119-0837

\section{U.S. Department of Energy}

Janet Appenzeller-W ing

1 (Uncontrolled)*

Environmental Restoration Division

U.S. Department of Energy

National Nuclear Security Administration

Nevada Site Office

P.O. Box 98518, M/S 505

Las Vegas, NV 89193-8518

Sabine Curtis

1 (Uncontrolled)*

Environmental Restoration Division

U.S. Department of Energy

National Nuclear Security Administration

Nevada Site Office

P.O. Box 98518, M/S 505

Las Vegas, NV 89193-8518

Sabrina Lawrence

1 (Controlled)*

Environmental Restoration Division

U.S. Department of Energy

National Nuclear Security Administration

Nevada Site Office

P.O. Box 98518, M/S 505

Las Vegas, NV 89193-8518 


\section{U.S. Department of Energy (continued)}

U.S. Department of Energy

National Nuclear Security Administration

Nevada Site Office

Southern Nevada Public Reading Facility

$\mathrm{C} / \mathrm{O}$ Nuclear Testing Archive

P.O. Box 98521, M/S 400

Las Vegas, NV 89193-8521

U.S. Department of Energy

National Nuclear Security Administration

Nevada Site Office

Technical Library

P.O. Box 98518

Las Vegas, NV 89193-8518

U.S. Department of Energy

Office of Scientific and Technical Information

P.O. Box 62

Oak Ridge, TN 37831-0062

\section{$\underline{\text { Bechtel Nevada }}$}

Correspondence Control

Bechtel Nevada

P.O. Box 98521, M/S CF008

Las Vegas, NV 89193-8521

Environmental Management Library

Bechtel Nevada

P.O. Box 98521, M/S NLV080

Las Vegas, NV 89193-8521

Kevin Campbell

Bechtel Nevada

P.O. Box 98521, M/S NTS306

Las Vegas, NV 89193-8521

Wayne Johnson

Bechtel Nevada

P.O. Box 98521, M/S NLV080

Las Vegas, NV 89193-8521
1 (Controlled) \&

1 (Uncontrolled)

1 (Uncontrolled) 


\section{$\underline{\text { Bechtel Nevada (continued) }}$}

Kraig Knapp

Bechtel Nevada

P.O. Box 98521, M/S NTS306

Las Vegas, NV 89193-8521

Patrick Morris

1 (Uncontrolled)*

Bechtel Nevada

P.O. Box 98521, M/S NTS306

Las Vegas, NV 89193-8521

Glenn Richardson

1 (Uncontrolled)*

Bechtel Nevada

P.O. Box 98521, M/S NTS306

Las Vegas, NV 89193-8521

$\underline{\text { Shaw Environmental, Inc. }}$

FFACO Coordinator

1 (Controlled)

Shaw Environmental

P.O. Box 93838, M/S 439

Las Vegas, NV 89193-3838

John Stokowski

1 (Uncontrolled)*

Shaw Environmental

P.O. Box 93838, M/S 439

Las Vegas, NV 89193-3838

\section{State of Nevada}

Manager, Northern Nevada

1 (Uncontrolled)

FFACO Public Reading Facility

Nevada State Library and Archives Federal Publications

100 North Stewart Street

Carson City, NV 89701-4285 
Post Closu re Inspection R eport

CAU 90 - Area 2 Bitcutter Revis ion: 0

Date: September 2003

THIS PAGE INTENTIONALLY LEFT BLANK 